\title{
PALAEOMAGNETIC SAMPLING OF BASIC DYKES AND REMNANT MAGNETISATION STUDIES ON OLD GNEISSES FROM WEST GREENLAND
}

\author{
Walter F. Fahrig
}

A joint programme has been embarked upon with the Geological Survey of Canada to use the palaeomagnetism of basic dykes as a possible correlation parameter between rocks of north-eastern Canada and those of West Greenland. As part of this programme field work during the summer was concentrated within the early Precambrian craton of West Greenland where sampling of Precambrian basic dykes was undertaken in three areas, namely the Fiskenæsset, S $\varnothing$ ndre Strømfjord and Godthåb areas.

In the Fiskenæsset area (see Kalsbeek, this report), 350 oriented cores were collected from 50 sites (4 swarms) in a zone from Ravns Stor $\varnothing$, north along the coast for about 100 kilometres. The S $\varnothing$ ndre Strømfjord sampling consisted of 200 oriented cores collected at 28 sites in a zone extending north about 100 kilometres from Kangâmiut. The dykes in this zone extend across the Nagssugtoqidian boundary (see Escher et al., this report) and have petrological peculiarities which make their palaeomagnetic study of particular interest.

Eighty cores from 10 sites were collected from the Amitsoq gneisses near the town of Godthåb. These gneisses and their relationships have been mapped in detail by McGregor (1973) and have yielded the oldest $\mathrm{Pb} / \mathrm{Pb}$ and $\mathrm{Rb} / \mathrm{Sr}$ ages known from rocks anywhere on Earth (OIGL \& McGregor, 1971). It seems of interest to determine whether the gneisses contain a stable remanent magnetisation and if so, at least to determine its relationship to the youngest deformational events in the region.

\section{References}

McGregor, V. R. 1973: The early Precambrian gneisses of the Godthåb district, West Greenland. Phil Trans. R. Soc. Lond. A, 273, 343-358.

Oxford Isotope Geology Laboratory \& McGregor, V. R. 1971: Isotopic dating of very early Precambrian amphibolite facies gneisses from the Godthaab district, West Greenland. Earth Planet. Sci. Lett. 12, 245-259.

Dept. of Energy, Mines \& Resources, Geological Survey of Canada, 601 Booth Street Ottawa 4, Ontario, Canada. 